\title{
Cultural adaptation and psychometric evaluation of the Kinyarwanda version of the problem areas in diabetes (PAID) questionnaire
}

\author{
Charilaos Lygidakis ${ }^{12^{*}} \mathbb{0}$, Jean Paul Uwizihiwe ${ }^{2,3}$, Michela Bia ${ }^{4}$, Per Kallestrup ${ }^{3}$, Damas Dukundane ${ }^{5}$, \\ Brenda Asiimwe-Kateera ${ }^{2,6}$, Simon Pierre Niyonsenga ${ }^{7}$ and Claus Vögele ${ }^{1}$
}

\begin{abstract}
Background: High prevalence rates in diabetes-related distress have been observed in several studies; however, in the region of Sub-Saharan Africa evidence is lacking as is, for example, the case for Rwanda, where diabetes prevalence is expected to increase over the next decade. The aim of this study is to report on the translation and cultural adaption of the problem areas in diabetes (PAID) questionnaire into Kinyarwanda and its psychometric properties.

Methods: The questionnaire was translated following a standard procedure. Interviews were conducted with 29 participants before producing a final version. For the psychometric evaluation, a sample of 266 patients with diabetes mellitus, aged 21-64 years old were examined. Participants either came from a separate cluster-randomised controlled trial or were recruited ad-hoc for this study. The evaluation included testing internal consistency, known groups validity, and construct validity. A series of confirmatory factor analysis were conducted investigating seven previously established factorial structures. An exploratory factor analysis (EFA) was also carried out to examine the structure further.
\end{abstract}

Results: The full scale showed good internal reliability (Cronbach's $a=0.88$ ). A four-factor solution previously tested in Spain with subdimensions of emotional, treatment, food-related and social-support problems demonstrated adequate approximate fit (RMSEA $=0.056 ; C F I=0.951 ; T L I=0.943)$. The EFA revealed a four-factor structure; however, two of these factors were not as homogeneous and easily interpretable as those of the Spanish model.

Conclusions: The psychometric properties of the Kinyarwanda version of PAID are acceptable. The questionnaire can be helpful in research and clinical practice in Rwanda, however certain cross-cultural differences should be taken into account.

Keywords: Problem areas in diabetes, PAID, Psychometrics, Validation study, Diabetes mellitus, Rwanda, Africa South of the Sahara

\footnotetext{
*Correspondence: lygidakis@gmail.com

${ }^{1}$ Department of Behavioural and Cognitive Sciences, University

of Luxembourg, Porte des Sciences 11, 4366 Esch-sur-Alzette, Luxembourg

Full list of author information is available at the end of the article
}

\section{Background}

Psychological distress refers to a range of emotional response to stressors $[1,2]$. It is experienced as the inability of effective coping, and is manifested by a change in emotional status, discomfort, communication of discomfort, and harm [1]. Patients with diabetes often report original author(s) and the source, provide a link to the Creative Commons licence, and indicate if changes were made. The images or other third party material in this article are included in the article's Creative Commons licence, unless indicated otherwise in a credit line to the material. If material is not included in the article's Creative Commons licence and your intended use is not permitted by statutory regulation or exceeds the permitted use, you will need to obtain permission directly from the copyright holder. To view a copy of this licence, visit http://creativecommons.org/licenses/by/4.0/. The Creative Commons Public Domain Dedication waiver (http://creativeco mmons.org/publicdomain/zero/1.0/) applies to the data made available in this article, unless otherwise stated in a credit line to the data. 
psychological distress as they need to cope with the burden of chronic treatment, self-care and self-management, and may experience lack of social support, fear of complications or hypoglycaemia, and powerlessness [3-5]. High prevalence rates in diabetes-related distress have been observed in several studies [6] and have been associated with poor glycaemic control, self-care, and quality of life $[7,8]$. A recent meta-analysis of studies in patients with type 2 diabetes mellitus estimated its prevalence at $36 \%$ [4], while Fisher et al. [9] reported rates of psychological distress in $42.1 \%$ of patients with type 1 diabetes mellitus. Nevertheless, studies in Sub-Saharan Africa are lacking [10-12], as is, for example, the case for Rwanda, where age-adjusted comparative diabetes prevalence in adults $20-79$ years has been estimated at $5.1 \%$ [13].

Increasing awareness of diabetes distress can help in researching specific interventions and its management in clinical settings. The problem areas in diabetes (PAID) questionnaire is a broadly employed self-report measure, which has been shown to be significantly associated with glycaemic control, adherence to treatment and complications [14], and to be linked to other associated constructs (e.g., general emotional distress, depression) $[14,15]$. It has been translated in many languages, has demonstrated high internal reliability and good responsiveness to change, and has been employed in a wide range of interventions [14-18].

The aim of this paper was to report on the translation and cultural adaption of the PAID questionnaire into Kinyarwanda and evaluate its psychometric properties.

\section{Material and methods}

\section{The problem areas in diabetes (PAID) questionnaire}

The questionnaire consists of 20 items representing different diabetes-related issues that may be a problem for the patient. Each item can be answered using a five-point Likert scale ranging from 0 (not a problem) to 4 (serious problem). The individual items can be summed up and multiplied by 1.25 to compute a total score, which ranges between 0 and 100, with higher scores indicating more severe distress [15].

A one-factor structure was originally proposed [14], however cross-cultural adaptations have revealed its multidimensional nature [8,18-24]. The constructs of some of the models are presented in Table 1.

\section{Translation and cross-cultural adaptation}

For the translation of the questionnaire, a standard protocol was followed [25]:

(a) Two native Rwandans, proficient in English, translated the questionnaire into Kinyarwanda independently, following an item intent guide. (b) The two translations were synthesised into one, addressing any discrepancies.

(c) Two English native speakers with excellent language skills in Kinyarwanda back-translated the questions into English, while blinded to the original version.

(d) Subsequently, the two backward translations were reconciled into one.

(e) All versions of the questionnaires were evaluated by an expert panel, consisting of the two Rwandan forward translators, one of the backward translators, an epidemiologist, a local bilingual representative, and the two researchers conducting the study. The aim was to appraise the results of the translations, evaluate their semantic, idiomatic, experiential and conceptual equivalence, and produce a prefinal version.

(f) A report was prepared providing an account of these steps, the controversial items and the ways they were resolved in the consensus translation. The report and the prefinal version were shared with the questionnaire developer, and consent was received.

The prefinal version was assessed with interviews using a sample of patients with diabetes mellitus. The objective was to evaluate: the comprehension of the translated questions and the answer categories; whether respondents could retrieve relevant information from memory; the effort requested to answer; the degree of interest; and social desirability bias. The interviews were conducted in rounds. To attain maximum variability of the participants, the interviews were conducted in four different hospitals. After each round, modifications were proposed for some items based on the interview transcripts and notes. A new iteration of the questionnaire was then prepared and tested in the following round. Lastly, a final version was produced and a report was made available to the developer.

\section{Psychometric evaluation and statistical analysis Participants}

The psychometric evaluation was initially designed as part of a cluster-randomised controlled trial (RCT) that aimed at determining the efficacy of an integrated mobile-health and community-health-worker programme for the management of diabetes in primary health care in Rwanda (ClinicalTrials.gov registration: NCT03376607) [26]. Patients living with diabetes were recruited in outpatient clinics for non-communicable diseases in seven out of nine hospitals of the trial between January and August 2019: Bushenge, Kibungo, Kibuye, Kinihira, Muhima, Ruhengeri, and Rwamagana. For the psychometric evaluation of the questionnaire, we 
Table 1 Constructs of the previously established models of PAID

\begin{tabular}{|c|c|c|c|c|c|c|}
\hline Question & $\begin{array}{l}\text { Two-factor } \\
\text { (Southern } \\
\text { US)[24] }\end{array}$ & $\begin{array}{l}\text { Two-factor } \\
\text { (Turkey)[23] }\end{array}$ & $\begin{array}{l}\text { Two-factor } \\
\text { (Iceland)[8] }\end{array}$ & $\begin{array}{l}\text { Three-factor } \\
\text { (Greece)[21] }\end{array}$ & $\begin{array}{l}\text { Four-factor } \\
\text { (The } \\
\text { Netherlands)[ } \\
\text { 19] }\end{array}$ & $\begin{array}{l}\text { Four-factor } \\
\text { (Spain) }[20]\end{array}$ \\
\hline $\begin{array}{l}\text { 1. Not having clear and concrete } \\
\text { goals for your diabetes care }\end{array}$ & $\begin{array}{l}\text { Lack of } \\
\text { confidence }\end{array}$ & $\begin{array}{l}\text { Diabetes } \\
\text { distress }\end{array}$ & $\begin{array}{c}\text { Management } \\
\text { of diabetes }\end{array}$ & $\begin{array}{l}\text { Emotional } \\
\text { problems }\end{array}$ & $\begin{array}{l}\text { Treatment } \\
\text { problems }\end{array}$ & $\begin{array}{l}\text { Treatment } \\
\text { problems }\end{array}$ \\
\hline $\begin{array}{l}\text { 2. Feeling discouraged with your } \\
\text { diabetes treatment plan }\end{array}$ & $\begin{array}{l}\text { Lack of } \\
\text { confidence }\end{array}$ & $\begin{array}{l}\text { Diabetes } \\
\text { distress }\end{array}$ & $\begin{array}{l}\text { Management } \\
\text { of diabetes }\end{array}$ & $\begin{array}{l}\text { Emotional } \\
\text { problems }\end{array}$ & $\begin{array}{l}\text { Treatment } \\
\text { problems }\end{array}$ & $\begin{array}{l}\text { Treatment } \\
\text { problems }\end{array}$ \\
\hline $\begin{array}{l}\text { 3. Feeling scared when you think } \\
\text { about living with diabetes }\end{array}$ & $\begin{array}{l}\text { Emotional } \\
\text { consequences }\end{array}$ & $\begin{array}{l}\text { Diabetes } \\
\text { distress }\end{array}$ & $\begin{array}{l}\text { Life with } \\
\text { diabetes }\end{array}$ & $\begin{array}{l}\text { Emotional } \\
\text { problems }\end{array}$ & $\begin{array}{l}\text { Emotional } \\
\text { problems }\end{array}$ & $\begin{array}{l}\text { Emotional } \\
\text { problems }\end{array}$ \\
\hline $\begin{array}{l}\text { 4. Uncomfortable social } \\
\text { situations related to your } \\
\text { diabetes care (e.g., people telling } \\
\text { you what to eat) }\end{array}$ & $\begin{array}{l}\text { Emotional } \\
\text { consequences }\end{array}$ & $\begin{array}{l}\text { Diabetes } \\
\text { distress }\end{array}$ & $\begin{array}{l}\text { Life with } \\
\text { diabetes }\end{array}$ & Food-related & Food-related & Food-related \\
\hline $\begin{array}{l}\text { 5. Feelings of deprivation } \\
\text { regarding food and meals }\end{array}$ & $\begin{array}{l}\text { Emotional } \\
\text { consequences }\end{array}$ & $\begin{array}{l}\text { Diabetes } \\
\text { distress }\end{array}$ & $\begin{array}{l}\text { Management } \\
\text { of diabetes }\end{array}$ & Food-related & Food-related & Food-related \\
\hline $\begin{array}{l}\text { 6. Feeling depressed when you } \\
\text { think about living with diabetes }\end{array}$ & $\begin{array}{l}\text { Emotional } \\
\text { consequences }\end{array}$ & $\begin{array}{l}\text { Diabetes } \\
\text { distress }\end{array}$ & $\begin{array}{l}\text { Life with } \\
\text { diabetes }\end{array}$ & $\begin{array}{l}\text { Emotional } \\
\text { problems }\end{array}$ & $\begin{array}{l}\text { Emotional } \\
\text { problems }\end{array}$ & $\begin{array}{l}\text { Emotional } \\
\text { problems }\end{array}$ \\
\hline $\begin{array}{l}\text { 7. Not knowing if your mood or } \\
\text { feelings are related to your } \\
\text { diabetes }\end{array}$ & $\begin{array}{l}\text { Emotional } \\
\text { consequences }\end{array}$ & $\begin{array}{l}\text { Diabetes } \\
\text { distress }\end{array}$ & $\begin{array}{l}\text { Life with } \\
\text { diabetes }\end{array}$ & $\begin{array}{l}\text { Emotional } \\
\text { problems }\end{array}$ & $\begin{array}{l}\text { Emotional } \\
\text { problems }\end{array}$ & $\begin{array}{l}\text { Emotional } \\
\text { problems }\end{array}$ \\
\hline $\begin{array}{l}\text { 8. Feeling overwhelmed by your } \\
\text { diabetes }\end{array}$ & $\begin{array}{l}\text { Emotional } \\
\text { consequences }\end{array}$ & $\begin{array}{l}\text { Diabetes } \\
\text { distress }\end{array}$ & $\begin{array}{l}\text { Life with } \\
\text { diabetes }\end{array}$ & $\begin{array}{l}\text { Emotional } \\
\text { problems }\end{array}$ & $\begin{array}{l}\text { Emotional } \\
\text { problems }\end{array}$ & $\begin{array}{l}\text { Emotional } \\
\text { problems }\end{array}$ \\
\hline $\begin{array}{l}\text { 9. Worrying about low blood } \\
\text { sugar reactions }\end{array}$ & $\begin{array}{l}\text { Emotional } \\
\text { consequences }\end{array}$ & $\begin{array}{l}\text { Diabetes } \\
\text { distress }\end{array}$ & $\begin{array}{c}\text { Management } \\
\text { of diabetes }\end{array}$ & $\begin{array}{l}\text { Emotional } \\
\text { problems }\end{array}$ & $\begin{array}{l}\text { Emotional } \\
\text { problems }\end{array}$ & $\begin{array}{l}\text { Emotional } \\
\text { problems }\end{array}$ \\
\hline $\begin{array}{l}\text { 10. Feeling angry when you think } \\
\text { about living with diabetes }\end{array}$ & $\begin{array}{l}\text { Emotional } \\
\text { consequences }\end{array}$ & $\begin{array}{l}\text { Diabetes } \\
\text { distress }\end{array}$ & $\begin{array}{l}\text { Life with } \\
\text { diabetes }\end{array}$ & $\begin{array}{l}\text { Emotional } \\
\text { problems }\end{array}$ & $\begin{array}{l}\text { Emotional } \\
\text { problems }\end{array}$ & $\begin{array}{l}\text { Emotional } \\
\text { problems }\end{array}$ \\
\hline $\begin{array}{l}\text { 11. Feeling constantly concerned } \\
\text { about food and eating }\end{array}$ & $\begin{array}{l}\text { Emotional } \\
\text { consequences }\end{array}$ & $\begin{array}{l}\text { Diabetes } \\
\text { distress }\end{array}$ & $\begin{array}{l}\text { Management } \\
\text { of diabetes }\end{array}$ & Food-related & Food-related & Food-related \\
\hline $\begin{array}{l}\text { 12. Worrying about the future } \\
\text { and the possibility of serious } \\
\text { complications }\end{array}$ & $\begin{array}{l}\text { Emotional } \\
\text { consequences }\end{array}$ & $\begin{array}{l}\text { Diabetes } \\
\text { distress }\end{array}$ & $\begin{array}{l}\text { Management } \\
\text { of diabetes }\end{array}$ & $\begin{array}{l}\text { Emotional } \\
\text { problems }\end{array}$ & $\begin{array}{l}\text { Emotional } \\
\text { problems }\end{array}$ & $\begin{array}{l}\text { Emotional } \\
\text { problems }\end{array}$ \\
\hline $\begin{array}{l}\text { 13. Feelings of guilt or anxiety } \\
\text { when you get off track with your } \\
\text { diabetes management }\end{array}$ & $\begin{array}{l}\text { Emotional } \\
\text { consequences }\end{array}$ & $\begin{array}{l}\text { Diabetes } \\
\text { distress }\end{array}$ & $\begin{array}{l}\text { Management } \\
\text { of diabetes }\end{array}$ & $\begin{array}{l}\text { Emotional } \\
\text { problems }\end{array}$ & $\begin{array}{l}\text { Emotional } \\
\text { problems }\end{array}$ & $\begin{array}{l}\text { Emotional } \\
\text { problems }\end{array}$ \\
\hline $\begin{array}{l}\text { 14. Not "accepting" your } \\
\text { diabetes }\end{array}$ & $\begin{array}{l}\text { Lack of } \\
\text { confidence }\end{array}$ & $\begin{array}{l}\text { Diabetes } \\
\text { distress }\end{array}$ & $\begin{array}{l}\text { Life with } \\
\text { diabetes }\end{array}$ & $\begin{array}{l}\text { Emotional } \\
\text { problems }\end{array}$ & $\begin{array}{l}\text { Emotional } \\
\text { problems }\end{array}$ & $\begin{array}{l}\text { Emotional } \\
\text { problems }\end{array}$ \\
\hline $\begin{array}{l}\text { 15. Feeling unsatisfied with your } \\
\text { diabetes physician }\end{array}$ & $\begin{array}{l}\text { Lack of } \\
\text { confidence }\end{array}$ & $\begin{array}{l}\text { Support- } \\
\text { related }\end{array}$ & $\begin{array}{l}\text { Life with } \\
\text { diabetes }\end{array}$ & $\begin{array}{l}\text { Emotional } \\
\text { problems }\end{array}$ & $\begin{array}{l}\text { Treatment } \\
\text { problems }\end{array}$ & Social support \\
\hline $\begin{array}{l}\text { 16. Feeling that diabetes is taking } \\
\text { up too much of your mental and } \\
\text { physical energy every day }\end{array}$ & $\begin{array}{l}\text { Lack of } \\
\text { confidence }\end{array}$ & $\begin{array}{l}\text { Support- } \\
\text { related }\end{array}$ & $\begin{array}{l}\text { Management } \\
\text { of diabetes }\end{array}$ & $\begin{array}{l}\text { Emotional } \\
\text { problems }\end{array}$ & $\begin{array}{l}\text { Emotional } \\
\text { problems }\end{array}$ & $\begin{array}{l}\text { Emotional } \\
\text { problems }\end{array}$ \\
\hline $\begin{array}{l}\text { 17. Feeling alone with your } \\
\text { diabetes }\end{array}$ & $\begin{array}{l}\text { Lack of } \\
\text { confidence }\end{array}$ & $\begin{array}{l}\text { Support- } \\
\text { related }\end{array}$ & $\begin{array}{l}\text { Life with } \\
\text { diabetes }\end{array}$ & Social support & Social support & Social support \\
\hline $\begin{array}{l}\text { 18. Feeling that your friends and } \\
\text { family are not supportive of your } \\
\text { diabetes management efforts }\end{array}$ & $\begin{array}{l}\text { Lack of } \\
\text { confidence }\end{array}$ & $\begin{array}{l}\text { Support- } \\
\text { related }\end{array}$ & $\begin{array}{l}\text { Life with } \\
\text { diabetes }\end{array}$ & Social support & Social support & Social support \\
\hline $\begin{array}{l}\text { 19. Coping with complications of } \\
\text { diabetes }\end{array}$ & $\begin{array}{c}\text { Emotional } \\
\text { consequences }\end{array}$ & $\begin{array}{l}\text { Diabetes } \\
\text { distress }\end{array}$ & $\begin{array}{l}\text { Management } \\
\text { of diabetes }\end{array}$ & $\begin{array}{l}\text { Emotional } \\
\text { problems }\end{array}$ & $\begin{array}{l}\text { Emotional } \\
\text { problems }\end{array}$ & $\begin{array}{l}\text { Emotional } \\
\text { problems }\end{array}$ \\
\hline $\begin{array}{l}\text { 20. Feeling "burned out" by the } \\
\text { constant effort needed to } \\
\text { manage diabetes }\end{array}$ & $\begin{array}{l}\text { Emotional } \\
\text { consequences }\end{array}$ & $\begin{array}{l}\text { Support- } \\
\text { related }\end{array}$ & $\begin{array}{l}\text { Life with } \\
\text { diabetes }\end{array}$ & $\begin{array}{l}\text { Emotional } \\
\text { problems }\end{array}$ & $\begin{array}{l}\text { Emotional } \\
\text { problems }\end{array}$ & $\begin{array}{l}\text { Emotional } \\
\text { problems }\end{array}$ \\
\hline
\end{tabular}

The different colours represent similarly identified constructs and highlight how they differ across the various translations 
used data exclusively from the baseline assessment of the patients participating in the RCT.

For the purpose of conducting the confirmatory factor analysis (CFA), at least 200 participants would be necessary $[20,22,27,28]$. The power analysis of the RCT indicated a sample size of 324 participants, which was also adequate for conducting the CFA. Nonetheless, the preenrolment screening revealed that a sufficient number of patients living with diabetes could not be recruited in the specific recruitment areas selected for the RCT [26]. Furthermore, logistical challenges impeded the prompt activation of the last two of the nine hospitals (Kabutare and Ruhango).

For these reasons, we recruited an additional sample specifically for the purposes of the psychometric evaluation. This supplementary cohort consisted of patients residing in additional zones in the catchment areas of same hospitals, except for the hospitals of Kibungo, Kibuye and Kinihira, where the number of patients was particularly low. The recruitment was carried out between June and December 2019. Both samples followed the same inclusion criteria: patients aged 21-80 years, and diagnosed with diabetes mellitus at least six months prior to study onset. Exclusion criteria for both samples were: illiteracy, severe hearing or visual impairments, severe mental health conditions, pregnancy or post-partum period. The classification of diabetes type was based on the patients' clinical records available at the hospitals.

As older people may present more multimorbidity which can impact emotional distress levels, only data from participants between 21 and 64 years old were included in the final sample for analysis [18]. As the precise date of diagnosis of diabetes was unknown for some participants, only those with at least one year of diagnosis were included so as to limit the effect of the emotional distress linked to recent diagnosis $[18,29]$.

\section{Statistical analyses}

Statistical analyses were performed on Stata version 16 and Mplus version 7. To assess construct validity, a series of CFA were conducted using previously established structures:

1. Two-factor model (rural African American women with type 2 diabetes mellitus in a Southern state of the US) [24]

2. Two-factor model (insulin-naïve type-2-diabetesmellitus patients in Turkey) [23]

3. Two-factor model (insulin-dependent patients in Iceland) [8]

4. Three-factor model (patients with type 2 diabetes mellitus in Greece) [21]
5. Four-factor model (The Netherlands) [19]

6. Four-factor model (Spain) [20]

For comparison, the one-factor model of the original study was also fitted to the data $[14,15]$. The factor structure of the Swedish version was not tested, as the authors replaced one item ("coping with complications of diabetes") with a new one ("feeling unsatisfied with your diabetes specialist nurse") to match the local health system [22].

The weighted least square mean and variance adjusted (WLSMV) estimator was used in the CFA, which is considered more appropriate for ordinal data [30]. The root mean square error of approximation (RMSEA), the comparative fit index (CFI), and the Tucker Lewis index (TLI) were used to examine the approximate model fit. For RMSEA, values of less than 0.05 were indicative of a close fit and those between 0.05 and 0.08 were interpreted as adequate fit $[31,32]$. The $90 \%$ confidence intervals of RMSEA were also evaluated, as they should be less than 0.05 for the lower bound and no worse than 0.08 for the upper one [31]. For CFI and TLI, values of 0.90 and above were regarded as acceptable fit [31,32]. Hu's and Bentler's recommendation of raising such cutoffs to 0.95 was also taken into account $[31,33]$. The relative $\chi^{2}$ was also calculated and a value of 2 or less was deemed adequate [31]. Finally, although the weighted root mean-square residual (WRMR) was computed and values of 1 or lower were considered a good fit, the experimental nature of this statistic thwarted drawing conclusions based on it [31, 32, 34]. A further evaluation of the structure was performed with an exploratory factor analysis (EFA) using the WLSMV estimator and Geomin rotation [35].

To assess internal reliability Cronbach's $\alpha$ and composite reliability were calculated. Mean differences in total score and in the scales of the model with the closest fit were investigated across socio-demographic and clinical groups with the Mann-Whitney U test (between two groups) and the Kruskal-Wallis test (between three or more groups), applying the Bonferroni correction in post-hoc tests for planned contrasts. This non-parametric approach was adopted as the total scale scores were derived from ordinal variables. Effect sizes were calculated based on $z$ values; $r$ of $0.10,0.30$ and 0.50 were interpreted as small, medium and large effects respectively [36]. For continuous variables, Spearman's correlation was used to determine which of them were associated with the total score and scales. Correlation coefficients below 0.4 were considered as weak, those between 0.4 and 0.7 as moderate, and those above 0.7 as strong $[37,38]$. 


\section{Ethical approval}

Ethical approval was obtained from the Rwanda National Ethics Committee (100/RNEC/2017; renewed in 113/ RNEC/2018 and 192/RNEC/2019; amended in 463/ RNEC/2017 and 688/RNEC/2019), and the Ethics Review Panel of the University of Luxembourg (ERP 17-014 D2Rwanda; amended in ERP 17-048 D2Rwanda).

\section{Results}

\section{Cultural adaptation}

The expert panel evaluated all translations and reached a consensus, particularly with regard to the items without precise translation into Kinyarwanda: "feeling depressed" (item 6), "mood" (item 7), "taking up energy" (item 16), "coping with" (item 19), "burned out" (item 20). Three rounds of interviews were conducted thereafter with a total of 29 participants with diabetes: 18 women and 11 men, with median age of 48.5 (range 31-67), and median education of 6 years (range $0-12$ ). Comprehension of the translated items was good and minor amendments were made to increase clarity and resolve any ambiguities. As there was no alternative way to express the concept of "mood", item 7 was modified (final back translation: "not knowing whether the way you feel in yourself is caused by your diabetes").

\section{Characteristics of the sample of the psychometric evaluation}

Two hundred and five participants were included from the RCT and 122 were recruited additionally for the purposes of the evaluation. Of these, our analyses focused on data from the 266 participants who were 21-64 years of age and with at least one year after diagnosis of diabetes. All participants were of Rwandan nationality and spoke Kinyarwanda. The sample characteristics are presented in Table 2. The two samples (RCT and additional cohort) did not differ significantly in terms of age, years of completed education, area of residency, living situation, employment type, type of diabetes and years since the diagnosis of diabetes. The mean total score of PAID for the sample was $48.21(\mathrm{SD}=18.83)$ and the median was $47.5(\mathrm{IQR}=36.25-61.25)$.

\section{Construct validity (confirmatory factor analysis)}

The $x^{2}$ of all models was significant and, therefore, we examined the approximate fit indices. The four-factor model from Spain showed the best fit with adequate-togood RMSEA, CFI and TLI (Table 3).

In the four-factor Spanish model, standardised factor loadings ranged from 0.451 to 0.762 for the emotional-problems scale; from 0.691 to 0.722 for the treatment-problems scale; from 0.485 to 0.689 for the food-related-problems scale; and from 0.536 to 0.838 for the social-support-problems scale (Table 4). Especially for the scales concerning food-related and emotional problems, the majority of the items did not load highly on their factors. Inter-factor correlations ranged from 0.500 to 0.730 showing sufficient discriminant validity, with the exception of the food-related and emotional-problems scales (inter-factor correlation $=0.906$ ).

Associations between socio-demographic and clinical variables and the questionnaire are presented in Table 5 . Age and gender had no impact on the PAID score, while educational level and area of residency showed a small effect. There was an inverse, albeit weak, correlation between self-rated overall health and all distress scales, but not for the treatment-problems scale. There were no differences between the types of diabetes, and the duration of the disease was only weakly correlated with the social-support-problems scale. Scores on this scale, however, did not differ across the groups of patients with different years of diabetes duration.

\section{Exploratory factor analysis}

An EFA was conducted to examine the structure further. Forced EFAs revealed four factors (eigenvalues above 1). As in the Spanish model, two items loaded on a treatment-problems factor, while three items loaded on a social-support-problems factor. Nevertheless, the other two factors were not as homogeneous as in the Spanish model. The three items related to food problems loaded highly on a single factor. Nonetheless, some of the items from the emotional-problems subdimension also loaded on this factor, rendering the interpretation of these two factors equivocal.

\section{Internal consistency}

Cronbach's $\alpha(0.88)$ and composite reliability (0.91) were good for the full scale. However, only the scale of emotional problems of the four-factor Spanish structure yielded a good Cronbach's $\alpha$ and composite reliability above 0.8 (Table 4 ).

\section{Discussion}

We translated and culturally adapted the PAID questionnaire into Kinyarwanda. To our knowledge this is the first study to provide a cross-culturally adapted and psychometrically evaluated version of a diabetes-specific distress questionnaire in Rwanda. The full scale showed a good internal reliability in line with previous studies $[8,15]$. The four-factor model previously tested in Spain showed an adequate approximate fit of the data [20].

Consistent with the results of other studies $[8,14,19$, 20, 22, 39], "worrying about the future and the possibility of serious complications" was the question with the highest reported distress $($ mean $=3.11, \mathrm{SD}=1.15$; median $=4$, 
Table 2 Sample characteristics



$S D$ standard deviation, IQR interquartile range

${ }^{\text {a }}$ The abilities were evaluated using a four-point Likert scale ranging from 1 (cannot do at all) to 4 (can do very well)

${ }^{b}$ The overall health was evaluated using a five-point Likert scale ranging from 1 (very poor) to 5 (very good) 
Table 3 Comparison of the different factor structures in the sample of under 65 years of age

\begin{tabular}{llllllll}
\hline Model & $\mathbf{X}^{\mathbf{2}}$ & $\mathbf{d f}$ & Relative $\mathbf{X}^{\mathbf{2}}$ & RMSEA (90\% CI) & CFI & TLI & WRMR \\
\hline One-factor (Original US) & 370.838 & 170 & 2.18 & $0.067(0.058-0.076)$ & 0.928 & 0.919 & 1.085 \\
Two-factor (Southern US) & 354.683 & 169 & 2.10 & $0.065(0.055-0.074)$ & 0.933 & 0.925 & 1.054 \\
Two-factor (Turkey) & 349.735 & 169 & 2.07 & $0.064(0.054-0.073)$ & 0.935 & 0.927 & 1.041 \\
Two-factor (Iceland) & 364.193 & 169 & 2.15 & $0.066(0.057-0.076)$ & 0.930 & 0.921 & 1.074 \\
Three-factor (Greece) & 327.065 & 167 & 1.96 & $0.060(0.051-0.070)$ & 0.942 & 0.934 & 1.003 \\
Four-factor (The Netherlands) & 307.809 & 164 & 1.88 & $0.058(0.048-0.068)$ & 0.948 & 0.940 & 0.962 \\
Four-factor (Spain) & 300.228 & 164 & 1.83 & $0.056(0.046-0.066)$ & 0.951 & 0.943 & 0.946 \\
\hline
\end{tabular}

$d f$ degrees of freedom, RMSEA root mean square error of approximation, CFI comparative fit index, TLITucker Lewis index, WRMR weighted root mean-square residual

Table 4 Psychometric properties of the Kinyarwanda version of PAID, replicating the four-factor Spanish model

\begin{tabular}{|c|c|c|c|c|}
\hline & Mean (SD), median (IQR) & $\begin{array}{l}\text { Standardised } \\
\text { loading }^{\mathrm{a}}\end{array}$ & S.E & $\mathrm{R}^{2}$ \\
\hline \multicolumn{5}{|l|}{ Emotional problems $(C R=0.875$, Cronbach's $a=0.85)$} \\
\hline 3. Feeling scared when you think about living with diabetes & $2.27(1.40), 2(1-4)$ & 0.709 & 0.037 & 0.503 \\
\hline 6. Feeling depressed when you think about living with diabetes & $2.08(1.45), 2(1-3)$ & 0.762 & 0.028 & 0.581 \\
\hline 7. Not knowing if your mood or feelings are related to your diabetes & $2.12(1.23), 2(1-3)$ & 0.481 & 0.047 & 0.231 \\
\hline 8. Feeling overwhelmed by your diabetes & $2.39(1.33), 2(1-4)$ & 0.659 & 0.041 & 0.435 \\
\hline 9. Worrying about low blood sugar reactions & $2.33(1.34), 2(1-4)$ & 0.451 & 0.047 & 0.204 \\
\hline 10. Feeling angry when you think about living with diabetes & $1.44(1.43), 1(0-3)$ & 0.661 & 0.039 & 0.437 \\
\hline 12. Worrying about the future and the possibility of serious complications & $3.11(1.15), 4(3-4)$ & 0.633 & 0.046 & 0.401 \\
\hline 13. Feelings of guilt or anxiety when you get off track with your diabetes management & $2.31(1.20), 3(1-3)$ & 0.460 & 0.050 & 0.212 \\
\hline 14. Not "accepting" your diabetes & $1.27(1.33), 1(0-2)$ & 0.556 & 0.047 & 0.309 \\
\hline $\begin{array}{l}\text { 16. Feeling that diabetes is taking up too much of your mental and physical energy every } \\
\text { day }\end{array}$ & $2.16(1.38), 2(1-3)$ & 0.637 & 0.044 & 0.405 \\
\hline 19. Coping with complications of diabetes & $2.26(1.30), 2(1-3)$ & 0.497 & 0.051 & 0.247 \\
\hline 20. Feeling "burned out" by the constant effort needed to manage diabetes & $1.88(1.43), 2(1-3)$ & 0.737 & 0.032 & 0.544 \\
\hline \multicolumn{5}{|l|}{ Treatment problems $(C R=0.666$, Cronbach's $a=0.63)$} \\
\hline 1. Not having clear and concrete goals for your diabetes care & $1.99(1.37), 2(1-3)$ & 0.722 & 0.064 & 0.521 \\
\hline 2. Feeling discouraged with your diabetes treatment plan & $1.71(1.43), 2(0-3)$ & 0.691 & 0.061 & 0.478 \\
\hline \multicolumn{5}{|l|}{ Food-related problems $(C R=0.602$, Cronbach's $a=0.54)$} \\
\hline $\begin{array}{l}\text { 4. Uncomfortable social situations related to your diabetes care (e.g., people telling you } \\
\text { what to eat) }\end{array}$ & $1.71(1.31), 2(1-3)$ & 0.556 & 0.049 & 0.309 \\
\hline 5. Feelings of deprivation regarding food and meals & $2.01(1.35), 2(1-3)$ & 0.485 & 0.052 & 0.235 \\
\hline 11. Feeling constantly concerned about food and eating & $2.38(1.39), 3(1-4)$ & 0.689 & 0.047 & 0.475 \\
\hline \multicolumn{5}{|l|}{ Social support problems ( $C R=0.745$, Cronbach's $a=0.61)$} \\
\hline 15. Feeling unsatisfied with your diabetes physician & $0.54(1.14), 0(0-0)$ & 0.536 & 0.077 & 0.287 \\
\hline 17. Feeling alone with your diabetes & $1.25(1.36), 1(0-2)$ & 0.838 & 0.044 & 0.702 \\
\hline $\begin{array}{l}\text { 18. Feeling that your friends and family are not supportive of your diabetes management } \\
\text { efforts }\end{array}$ & $1.38(1.46), 1(0-3)$ & 0.718 & 0.045 & 0.516 \\
\hline
\end{tabular}

$S D$ standard deviation, IQR interquartile range, $C R$ composite reliability

a All standardised loadings were found significant $(p<0.001)$

$\mathrm{IQR}=3-4)$ : it was perceived as a somewhat serious or serious problem by $77.4 \%$ of the participants. Nonetheless, the other items receiving high scores were "feeling overwhelmed by your diabetes" (mean $=2.39, \mathrm{SD}=1.33$; median $=2$, IQR $=1-4 ; 49.8 \%$ of the participants endorsed it as a somewhat serious or serious problem) and "feeling constantly concerned about food and eating" ( mean $=2.38, \mathrm{SD}=1.39$; median $=3, \mathrm{IQR}=1-4 ; 50.6 \%$ of participants endorsed it as a somewhat serious or serious problem), indicating different problem areas compared with other cultures. 
Table 5 Relationships between socio-demographic and clinical variables and PAID

\begin{tabular}{|c|c|c|c|c|c|}
\hline & $\begin{array}{l}\text { Emotional problems } \\
\text { (range 0-60) }\end{array}$ & $\begin{array}{l}\text { Treatment } \\
\text { problems }{ }^{\mathrm{a}} \text { (range } \\
0-10)\end{array}$ & $\begin{array}{l}\text { Food-related } \\
\text { problems }{ }^{a} \text { (range } \\
0-15)\end{array}$ & $\begin{array}{l}\text { Social support } \\
\text { problems }^{\mathrm{a}} \text { (range } \\
0-15 \text { ) }\end{array}$ & Total score $^{\mathrm{a}}$ (range $\left.0-100\right)$ \\
\hline \multicolumn{6}{|l|}{ Gender } \\
\hline Female, median (IQR) & $32.5(23.75-41.25)$ & $5(2.5-7.5)$ & $7.5(5-11.25)$ & $2.5(1.25-7.5)$ & $47.5(36.25-62.5)$ \\
\hline Male, median (IQR) & $31.25(23.75-41.25)$ & $3.75(2.5-6.25)$ & $7.5(5-8.75)$ & $2.5(1.25-6.25)$ & $47.5(33.75-60)$ \\
\hline Mann-Whitney test & $\begin{array}{l}z=0.227 \\
p=0.821\end{array}$ & $\begin{array}{l}z=1.167 \\
p=0.244\end{array}$ & $\begin{array}{l}z=0.630 \\
p=0.530\end{array}$ & $\begin{array}{l}z=0.589 \\
p=0.557\end{array}$ & $\begin{array}{l}z=0.737 \\
p=0.462\end{array}$ \\
\hline ES & $r=0.014$ & $r=0.072$ & $r=0.039$ & $r=0.036$ & $r=0.045$ \\
\hline Age, Spearman's correlation & $\begin{array}{l}r_{s}=-0.069 \\
p=0.263\end{array}$ & $\begin{array}{l}r_{s}=0.017 \\
p=0.780\end{array}$ & $\begin{array}{l}r_{s}=0.072 \\
p=0.244\end{array}$ & $\begin{array}{l}r_{s}=-0.075 \\
p=0.224\end{array}$ & $\begin{array}{l}r_{s}=-0.046 \\
p=0.451\end{array}$ \\
\hline \multicolumn{6}{|l|}{ Age } \\
\hline 21-44 years, median (IQR) & $32.5(25-42.5)$ & $3.75(2.5-6.25)$ & $6.25(5-10)$ & $3.75(1.25-7.5)$ & $48.75(36.25-61.25)$ \\
\hline $45-54$ years, median (IQR) & $31.25(21.25-41.25)$ & $5(1.25-6.25)$ & $8.75(5-11.25)$ & $2.5(0-5)$ & $47.5(35-63.75)$ \\
\hline $55-64$ years, median (IQR) & $31.25(23.75-41.25)$ & $5(2.5-7.5)$ & $7.5(5-11.25)$ & $2.5(1.25-6.25)$ & $46.25(33.75-60.625)$ \\
\hline Kruskal Wallis H & $\begin{array}{l}H(2)=0.935 \\
p=0.627\end{array}$ & $\begin{array}{l}H(2)=0.493 \\
p=0.782\end{array}$ & $\begin{array}{l}H(2)=1.414 \\
p=0.493\end{array}$ & $\begin{array}{l}H(2)=4.118 \\
p=0.128\end{array}$ & $\begin{array}{l}H(2)=0.815 \\
p=0.665\end{array}$ \\
\hline \multicolumn{6}{|l|}{ Area of residency } \\
\hline Urban, median (IQR) & 29.375 (18.75-39.375) & $3.75(1.25-6.25)$ & $6.25(5-10)$ & $2.5(0-6.875)$ & $45(26.875-56.875)$ \\
\hline Rural or semi, median (IQR) & $32.5(25-42.5)$ & $5(2.5-7.5)$ & $7.5(5-10)$ & $2.5(1.25-6.25)$ & $49.375(37.5-63.125)$ \\
\hline Mann-Whitney test & $\begin{array}{l}z=-2.211 \\
p=0.027\end{array}$ & $\begin{array}{l}z=-1.684 \\
p=0.092\end{array}$ & $\begin{array}{l}z=-1.355 \\
p=0.176\end{array}$ & $\begin{array}{l}z=-1.612 \\
p=0.107\end{array}$ & $\begin{array}{l}z=-2.133 \\
p=0.033\end{array}$ \\
\hline ES & $r=-0.136$ & $r=-0.104$ & $r=-0.083$ & $r=-0.099$ & $r=-0.131$ \\
\hline $\begin{array}{l}\text { Years of completed education, } \\
\text { Spearman's correlation }\end{array}$ & $\begin{array}{l}r_{s}=-0.214 \\
p=0.001\end{array}$ & $\begin{array}{l}r_{s}=-0.203 \\
p=0.001\end{array}$ & $\begin{array}{l}r_{s}=-0.115 \\
p=0.061\end{array}$ & $\begin{array}{l}r_{s}=-0.214 \\
p=0.001\end{array}$ & $\begin{array}{l}r_{s}=-0.240 \\
p<0.001\end{array}$ \\
\hline \multicolumn{6}{|l|}{ Highest degree obtained } \\
\hline $\begin{array}{l}\text { No formal education or primary } \\
\text { school, median (IQR) }\end{array}$ & $33.75(26.25-43.75)$ & $5(2.5-7.5)$ & $7.5(5-11.25)$ & $3.75(1.25-7.5)$ & $51.25(41.25-63.75)$ \\
\hline $\begin{array}{l}\text { Secondary school, university, } \\
\text { vocational school or postgradu- } \\
\text { ate, median (IQR) }\end{array}$ & $26.875(20-35.635)$ & $3.75(1.25-6.25)$ & $7.5(5-8.75)$ & $2.5(0-5)$ & $41.25(30-52.5)$ \\
\hline Mann-Whitney test & $\begin{array}{l}z=3.777 \\
p<0.001\end{array}$ & $\begin{array}{l}z=3.406 \\
p=0.001\end{array}$ & $\begin{array}{l}z=1.635 \\
p=0.102\end{array}$ & $\begin{array}{l}z=2.183 \\
p=0.029\end{array}$ & $\begin{array}{l}z=3.818 \\
p<0.001\end{array}$ \\
\hline ES & $r=0.233$ & $r=0.210$ & $r=0.101$ & $r=0.135$ & $r=0.236$ \\
\hline $\begin{array}{l}\text { Self-rated overall health, Spearman's } \\
\text { correlation }\end{array}$ & $\begin{array}{l}r_{s}=-0.245 \\
p<0.001\end{array}$ & $\begin{array}{l}r_{s}=-0.078 \\
p=0.205\end{array}$ & $\begin{array}{l}r_{s}=-0.183 \\
p=0.003\end{array}$ & $\begin{array}{l}r_{s}=-0.306 \\
p<0.001\end{array}$ & $\begin{array}{l}r_{s}=-0.266 \\
p<0.001\end{array}$ \\
\hline $\begin{array}{l}\text { Moderate, poor, very poor, median } \\
\text { (IQR) }\end{array}$ & $33.75(26.25-43.75)$ & $5(2.5-6.25)$ & $7.5(5-11.25)$ & $3.75(1.25-7.5)$ & $52.5(41.25-65$ \\
\hline Very good or good, median (IQR) & $27.5(20-35.635)$ & $3.75(1.25-6.875)$ & $6.25(5-8.75)$ & $1.25(0-5)$ & $42.5(28.125-52.5)$ \\
\hline Mann-Whitney test & $\begin{array}{l}z=3.617 \\
p<0.001\end{array}$ & $\begin{array}{l}z=1.136 \\
p=0.258\end{array}$ & $\begin{array}{l}z=2.183 \\
p=0.029\end{array}$ & $\begin{array}{l}z=4.172 \\
p<0.001\end{array}$ & $\begin{array}{l}z=3.787 \\
p<0.001\end{array}$ \\
\hline ES & $r=0.222$ & $r=0.070$ & $r=0.134$ & $r=0.256$ & $r=0.233$ \\
\hline \multicolumn{6}{|l|}{ Types of diabetes } \\
\hline Type I, median (IQR) & $30(25-38.75)$ & $3.75(1.25-6.25)$ & $6.25(5-8.75)$ & $2.5(1.25-6.25)$ & $47.5(31.25-56.25)$ \\
\hline Type II, median (IQR) & $31.25(23.75-41.875)$ & $5(2.5-6.875)$ & $7.5(5-10.625)$ & $2.5(0.625-6.25)$ & $47.5(36.25-62.5)$ \\
\hline Mann-Whitney test & $\begin{array}{l}z=-0.681 \\
p=0.499\end{array}$ & $\begin{array}{l}z=-0.767 \\
p=0.446\end{array}$ & $\begin{array}{l}z=-1.960 \\
p=0.050\end{array}$ & $\begin{array}{l}z=-0.265 \\
p=0.794\end{array}$ & $\begin{array}{l}z=-0.874 \\
p=0.385\end{array}$ \\
\hline ES & $r=-0.043$ & $r=-0.048$ & $r=-0.123$ & $r=-0.017$ & $r=-0.055$ \\
\hline $\begin{array}{l}\text { Years since diagnosis, Spearman's } \\
\text { correlation }\end{array}$ & $\begin{array}{l}r_{s}=0.087 \\
p=0.155\end{array}$ & $\begin{array}{l}r_{s}=0.084 \\
p=0.171\end{array}$ & $\begin{array}{l}r_{s}=0.019 \\
p=0.763\end{array}$ & $\begin{array}{l}r_{s}=0.140 \\
p=0.022\end{array}$ & $\begin{array}{l}r_{s}=0.100 \\
p=0.104\end{array}$ \\
\hline \multicolumn{6}{|l|}{ Years of duration of diabetes } \\
\hline Up to 2 years, median (IQR) & $31.25(21.25-37.5)$ & $3.75(1.25-6.25)$ & $7.5(5-10)$ & $2.5(0-5)$ & $45(33.75-57.5)$ \\
\hline 3 to 5 years, median (IQR) & $32.5(24.375-41.25)$ & $3.75(2.5-6.25)$ & $8.75(6.25-10)$ & $2.5(1.25-5)$ & $50(38.125-61.875)$ \\
\hline 6 or more years, median (IQR) & $32.5(25-42.5)$ & $5(2.5-7.5)$ & $7.5(5-10.625)$ & $5(1.25-7.5)$ & $48.75(38.125-63.75)$ \\
\hline Kruskal Wallis H & $\begin{array}{l}H(2)=2.853 \\
p=0.240\end{array}$ & $\begin{array}{l}H(2)=2.681 \\
p=0.262\end{array}$ & $\begin{array}{l}\mathrm{H}(2)=1.581 \\
p=0.454\end{array}$ & $\begin{array}{l}\mathrm{H}(2)=4.293 \\
p=0.117\end{array}$ & $\begin{array}{l}\mathrm{H}(2)=3.056 \\
p=0.217\end{array}$ \\
\hline
\end{tabular}


Table 5 (continued)

$S D$ standard deviation, $I Q R$ interquartile range, $E S$ effect size

${ }^{a}$ The total PAID score is the sum of the 20 items multiplied by 1.25. The four scales of the Spanish model are calculated in a similar way

Dissatisfaction with one's diabetes physician was considered the least distressing item (mean $=0.54, \mathrm{SD}=1.14$; median $=0, \mathrm{IQR}=0-0 ; 77.1 \%$ of the participants reject the idea of this being a problem) in concordance with the research of Polonsky et al. in the United States and Huang et al. in Taiwan $[14,39]$. Interestingly, in previous studies this item also yielded a low mean score, however, not as low as the perceived distress deriving from the lack of support of one's diabetes management efforts by friends and family $[19,21]$. The effect of the setting and the presence of health care providers may explain the result in Rwanda, as participants completed the questionnaire in nurse-run clinics for non-communicable diseases in hospitals [14].

The mean total PAID score in our study was notably high (48.21). One hundred eighty-three (68.8\%) had a total score of 40 or higher, which suggests severe diabetes-specific emotional problems according to a previously designated cut-off score $[7,8]$. Cross-cultural differences in the PAID score have been observed elsewhere [3, 10, 19]. In the study of Snoek et al. [19], the Dutch sample showed lower distress compared with the demographically- and clinically-comparable American one, although both populations regarded similar problem areas as the most distressing. Ogbera and Adeyemi-Doro [10] documented a mean PAID score of 21.3 in patients with type 2 diabetes mellitus in Lagos. Spencer et al. [3] identified a significant difference between inner-city African American and Hispanic patients with type 2 diabetes mellitus in Detroit (mean scores of 15.59 vs. 36.75 respectively). Melkus et al. [40] found a mean PAID score of 49.3 in a small sample of African American women. Significant differences on distress have also been observed in ethnic minorities in the Netherlands [41, 42]. It should be noted, lastly, that the cut-off was established in Western populations (one standard deviation above the mean) [2,43] and may not be universally applicable.

The observed higher PAID score may be partially explained by the coexistence of general emotional distress, including depression and anxiety, the ways life and environmental stressors are perceived and prioritised, and the temperament $[3,44,45]$. Depression and diabetes-specific distress are substantially overlapping constructs, with common symptoms and presentations [4, 7]. The questionnaire and some of its items have shown a strong correlation with several related non-diseasespecific constructs [15]. The performance of the questionnaire as a screening tool for clinical and subclinical depression was documented in Germany [7]. A recent study in Rwanda screened patients with type 2 diabetes mellitus for depression using the Patient Health Questionnaire-9 (PHQ-9) and reported minimal to severe depression in $83.8 \%$ of the sample. The authors suggested the possibility of linking such a high prevalence to the 1994 Genocide against the Tutsi, as the population had been more exposed to general emotional distress [46]. Paucity of health care professionals and poor access to health care services as a result of the Genocide should also be considered [47]. Yet, it is important to distinguish depression from diabetes-specific distress, for they can present alone or simultaneously, and their coexistence can be inter-dependent or not. Notably, diabetes-specific distress has been shown to be an independent predictor of impaired glycaemic control and poor self-care [2, 7 , 14 .

Another indicator of cross-cultural differences in experiencing diabetes-specific distress is the wide range of reported factorial structures, with some studies confirming the unidimensional original model and others suggesting up to four factors [8, 18-21, 23, 24, 39]. While many studies observed one large emotional-problems factor [18-21], the food-related factor was not always distinct [23, 24]. The Spanish model, which yielded the best approximate fit, differs from the Dutch model only in integrating the item "feeling unsatisfied with your diabetes physician" into the factor of social-support problems $[19,20]$. Other studies regarded this item as a social-support problem too [23, 48]. All these findings suggest caution concerning the cross-culture applicability of PAID [48].

Unlike other studies [4, 12, 19], but in accordance with the results of Ogbera and Adeyemi-Doro [10], there was no link between female gender and diabetes-specific distress. There was a small effect of the type of residency area, with participants coming from more rural areas reporting higher distress levels. Moreover, a weak inverse correlation was observed between the years of completed education and the total PAID score. Having no formal education or having completed primary school was related to higher distress. A decreased ability of coping with the management of the diseases may be linked to these results [49].

The presentation of diabetes-specific distress may differ between patients with type 1 and type 2 diabetes mellitus. For instance, the former may present higher fear of hypoglycaemia [4]. Although we observed no significant 
differences between the two types, our sample consisted predominantly of patients with type 2 diabetes mellitus. Such a distinction should be considered with caution on the grounds of possible misclassification and possible atypical disease forms [50-53]. There may also be a separate effect of the treatment type, specifically related to the use of insulin [21], however information on insulin use was not collected in the present study.

An additional study limitation was the lack of testing for convergent validity, as it was not possible to identify another established and previously validated generic or diabetesspecific tool in the Rwandan population. Test-retest reliability was not carried out, and further research is therefore needed in this respect. Moreover, we were unable to evaluate the correlation of PAID with HbA1c, as this test was not yet performed in patients with diabetes systematically and we could not carry it out ad-hoc for the entire study sample. Finally, while efforts were made to investigate comorbidity, it was difficult to obtain reliable diagnoses from the medical records of the patients. Yet, hypertension, which was easier to verify, was estimated at $42.48 \%$ of the sample and had a small effect on distress $(\mathrm{z}=2.240, p=0.025, \mathrm{r}=0.137)$.

\section{Conclusions}

The PAID questionnaire is brief and easy to administer and could help both researchers and clinicians to identify appropriate interventions and targeting at-risk populations. We could show important differences between its Kinyarwanda version and those studied on other populations, such as the way disease-specific distress was experienced and the factors that cause the most distress $[8,14,19,20$, $22,39]$. These results urge further examination of cultural differences in the questionnaire's underlying concepts.

\section{Appendix: The Kinyarwanda version of the problem areas in diabetes (PAID) questionnaire \\ INGORANE ZIKOMOKA KURI DIYABETE}

AMABWIRIZA: Ni iyihe muri izi ngorane za diyabete zikurikira iguteye ikibazo muri iki gihe?

Shyira mu ruziga umubare utanga igisubizo kibereye kuruta ibindi kuri wowe. Tanga igisubizo kuri buri kibazo.

\begin{tabular}{llllll}
\hline INGORANE & Nta kibazo & Ikibazo gito & $\begin{array}{l}\text { Ikibazo } \\
\text { kiringaniye }\end{array}$ & $\begin{array}{l}\text { Ikibazo gisa } \\
\text { n'igikomeye }\end{array}$ & $\begin{array}{l}\text { Ikibazo } \\
\text { gikomeye }\end{array}$ \\
\hline $\begin{array}{l}\text { 1. Kutagira intego } \\
\text { zisobanutse }\end{array}$ & 0 & 1 & 2 & 3 & 4 \\
$\begin{array}{l}\text { kandi zifatika } \\
\text { mu kwiyitaho } \\
\text { kuri diyabete } \\
\text { yawe? }\end{array}$ & & & & \\
\hline
\end{tabular}

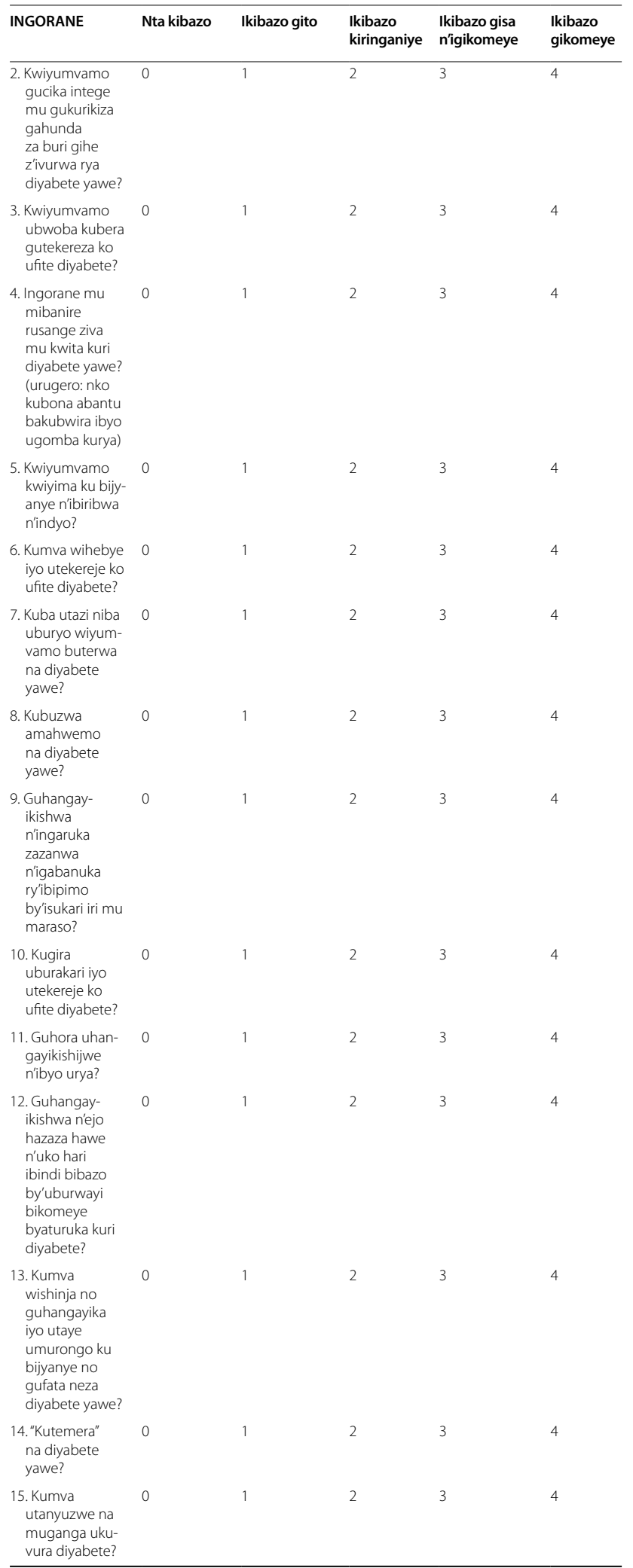




\begin{tabular}{|c|c|c|c|c|c|}
\hline INGORANE & Nta kibazo & Ikibazo gito & $\begin{array}{l}\text { Ikibazo } \\
\text { kiringaniye }\end{array}$ & $\begin{array}{l}\text { Ikibazo gisa } \\
\text { n'igikomeye }\end{array}$ & $\begin{array}{l}\text { Ikibazo } \\
\text { gikomeye }\end{array}$ \\
\hline $\begin{array}{l}\text { 16. Kumva } \\
\text { ubujijwe } \\
\text { amahwemo } \\
\text { bikomeye na } \\
\text { diyabete mu } \\
\text { mutwe no mu } \\
\text { mubiri buri } \\
\text { munsi? }\end{array}$ & 0 & 1 & 2 & 3 & 4 \\
\hline $\begin{array}{l}\text { 17. Kumva ko uri } \\
\text { wenyine kubera } \\
\text { diyabete yawe? }\end{array}$ & 0 & 1 & 2 & 3 & 4 \\
\hline $\begin{array}{l}\text { 18. Kumva inshuti } \\
\text { n'umuryango } \\
\text { batagushy- } \\
\text { igikira mu } \\
\text { buryo uharanira } \\
\text { kwiyitaho mu } \\
\text { burwayi bwa } \\
\text { diyabete? }\end{array}$ & 0 & 1 & 2 & 3 & 4 \\
\hline $\begin{array}{l}\text { 19. Guhangana } \\
\text { n'ibindi bibazo } \\
\text { by'uburwayi } \\
\text { bituruka kuri } \\
\text { diyabete? }\end{array}$ & 0 & 1 & 2 & 3 & 4 \\
\hline $\begin{array}{l}\text { 20. Kwiyumvamo } \\
\text { ko urambiwe } \\
\text { cyane kubera } \\
\text { imbaraga } \\
\text { zisabwa iteka } \\
\text { mu gucunga } \\
\text { diyabete? }\end{array}$ & 0 & 1 & 2 & 3 & 4 \\
\hline
\end{tabular}

\section{Abbreviations}

CFA: Confirmatory factor analysis; CFI: Comparative fit index; DF: Degrees of freedom; EFA: Exploratory factor analysis; ES: Effect size; HbA1c: Haemoglobin A1C; IQR: Interquartile range; PAID: Problem areas in diabetes; RCT: Randomised controlled trial; RMSEA: Root mean square error of approximation; SD: Standard deviation; TLI:Tucker Lewis index; WLSMV: Weighted least square mean and variance; WRMR: Weighted root mean-square residual.

\section{Acknowledgements}

We extend our gratitude to Mireille Uwineza, Marie Rose Uwizeye, Anastase Nzeyimana, Esperance Mukangango, Hortense Umurerwa, and Janvier Kayitare for their help in conducting the cognitive interviews and data collection and to Josiane Uwineza, John Doldo IV and Jake Freyer for the translations and participation in the expert panel. Finally, we would like to thank Dr Garry Welch for his support and guidance.

\section{Authors' contributions}

$\mathrm{CL}, \mathrm{JPU}, \mathrm{CV}$ and PK conceptualised the study and developed the design. CL overviewed parts of the data collection, conducted statistical analyses and drafted the manuscript. JPU overviewed the data collection, analysis and interpretation of results. MB carried out the statistical analysis. DD and BAK participated in the translations and expert panel sessions. All authors contributed to editing and revising the manuscript critically.

\section{Funding}

The study was supported by the Karen Elise Jensens Fond, and the Universities of Luxembourg and Aarhus. The funding sources had no role in study design, data collection and analysis, interpretation of data, or writing the manuscript.

\section{Availability of data and materials}

The data used to support the findings of this study are restricted by the Government of Rwanda and cannot be released or shared partially or totally with third parties without the written permission of the Rwanda Biomedical Center. Data are available from the corresponding author for researchers who meet the criteria for access to confidential data, and only after authorisation from the Rwanda Biomedical Center.

\section{Declarations}

\section{Ethics approval and consent to participate}

Ethical approval was obtained from the Rwanda National Ethics Committee (100/RNEC/2017; renewed in 113/RNEC/2018 and 192/RNEC/2019; amended in 463/RNEC/2017 and 688/RNEC/2019), and the Ethics Review Panel of the University of Luxembourg (ERP 17-014 D2Rwanda; amended in ERP 17-048 D2Rwanda). All the participants signed informed consents previously approved by the two aforementioned ethics committees.

\section{Consent for publication}

Not applicable.

\section{Competing interests}

The authors declare no known conflicts of interest.

\section{Author details}

'Department of Behavioural and Cognitive Sciences, University of Luxembourg, Porte des Sciences 11, 4366 Esch-sur-Alzette, Luxembourg. ${ }^{2}$ College of Medicine and Health Sciences, University of Rwanda, Huye, Rwanda. ${ }^{3}$ Centre for Global Health, Department of Public Health, Aarhus University, Aarhus, Denmark. ${ }^{4}$ Luxembourg Institute of Socio-Economic Research (LISER), Esch-sur-Alzette, Luxembourg. ${ }^{5}$ Butaro Cancer Centre of Excellence, Burera, Rwanda. ${ }^{6}$ AIDS Healthcare Foundation (AHF) Rwanda, Kigali, Rwanda. ${ }^{7}$ Rwanda Biomedical Center, Kigali, Rwanda.

Received: 3 July 2020 Accepted: 14 July 2021

Published online: 22 July 2021

\section{References}

1. Ridner SH. Psychological distress: concept analysis. J Adv Nurs. 2004;45:536-45.

2. Snoek FJ, Bremmer MA, Hermanns N. Constructs of depression and distress in diabetes: time for an appraisal. Lancet Diabetes Endocrinol. 2015;3:450-60. https://doi.org/10.1016/S2213-8587(15)00135-7.

3. Spencer MS, Kieffer EC, Sinco BR, Palmisano G, Guzman JR, James SA, et al. Diabetes-specific emotional distress among African Americans and Hispanics with type 2 diabetes. J Health Care Poor Underserv. 2006;17:88-105.

4. Perrin NE, Davies MJ, Robertson N, Snoek FJ, Khunti K. The prevalence of diabetes-specific emotional distress in people with Type 2 diabetes: a systematic review and meta-analysis. Diabet Med. 2017;34:1508-20.

5. Mayega RW, Ekirapa E, Kirunda B, Nalwadda C, Aweko J, Tomson G, et al. 'What kind of life is this?' Diabetes related notions of wellbeing among adults in eastern Uganda and implications for mitigating future chronic disease risk. BMC Public Health. 2018;18:1409. https://doi.org/10.1186/ s12889-018-6249-0.

6. Fisher L, Hessler DM, Polonsky WH, Mullan J. When is diabetes distress clinically meaningful? Diabetes Care. 2012;35:259-64.

7. Hermanns N, Kulzer B, Krichbaum M, KubiakT, HaakT. How to screen for depression and emotional problems in patients with diabetes: comparison of screening characteristics of depression questionnaires, measurement of diabetes-specific emotional problems and standard clinical assessment. Diabetologia. 2006:49:469-77.

8. Sigurdardottir AK, Benediktsson R. Reliability and validity of the Icelandic version of the problem area in diabetes (PAID) scale. Int J Nurs Stud. 2008;45:526-33.

9. Fisher L, Hessler D, Polonsky W, Strycker L, Masharani U, Peters A. Diabetes distress in adults with type 1 diabetes: prevalence, incidence and change over time. J Diabetes Complicat. 2016;30:1123-8.

10. Ogbera A, Adeyemi-Doro A. Emotional distress is associated with poor self care in type 2 diabetes mellitus. J Diabetes. 2011;3:348-52.

11. Stephani V, Opoku D, Beran D. Self-management of diabetes in SubSaharan Africa: a systematic review. BMC Public Health. 2018;18:1148. https://doi.org/10.1186/s12889-018-6050-0.

12. Ramkisson S, Pillay BJ, Sartorius B. Anxiety, depression and psychological well-being in a cohort of South African adults with Type 2 diabetes mellitus. S Afr J Psychiatr. 2016;22:935. 
13. International Diabetes Federation. IDF Diabetes Atlas, 9th edn. Brussels, Belgium: 2019. Available at: https://www.diabetesatlas.org.

14. Polonsky WH, Anderson BJ, Lohrer PA, Welch G, Jacobson AM, Aponte $J$ E, et al. Assessment of diabetes-related distress. Diabetes Care. 1995;18:754-60.

15. Welch G, Weinger K, Anderson B, Polonsky WH. Responsiveness of the problem areas in diabetes (PAID) questionnaire. Diabet Med. 2003;20:69-72.

16. Speight J, Reaney MD, Barnard KD. Not all roads lead to Rome-a review of quality of life measurement in adults with diabetes. Diabet Med. 2009;26:315-27.

17. Fenwick EK, Rees G, Holmes-Truscott E, Browne JL, Pouwer F, Speight J. What is the best measure for assessing diabetes distress? A comparison of the problem areas in diabetes and diabetes distress scale: results from Diabetes MILES-Australia. J Health Psychol. 2016;23:667-80. https://doi. org/10.1177/1359105316642006.

18. Venkataraman K, Tan LSM, Bautista DCT, Griva K, Zuniga YLM, Amir M, et al. Psychometric properties of the problem areas in diabetes (PAID) instrument in Singapore. PLoS ONE. 2015;10:1-11. https://doi.org/10. 1371/journal.pone.0136759.

19. Snoek FJ, Pouwer F, Welch GW, Polonsky WH. Diabetes-related emotional distress in Dutch and U.S. diabetic patients: cross-cultural validity of the problem areas in diabetes scale. Diabetes Care. 2000;23:1305LP - 1309.

20. Beléndez M, Hernández-Mijares A, Marco J, Domínguez JR, Pomares FJ. Validation of the Spanish version of the problem areas in diabetes (PAIDSP) scale. Diabetes Res Clin Pract. 2014;106:e93-5. https://doi.org/10. 1016/j.diabres.2014.09.012.

21. Papathanasiou A, Koutsovasilis A, Shea S, Philalithis A, Papavasiliou S, Melidonis A, et al. The problem areas in diabetes (PAID) scale: psychometric evaluation survey in a Greek sample with type 2 diabetes. J Psychiatr Ment Health Nurs. 2014;21:345-53.

22. Amsberg $S$, Wredling R, Lins P-E, Adamson U, Johansson U-B. The psychometric properties of the Swedish version of the problem areas in diabetes scale (Swe-PAID-20): scale development. Int J Nurs Stud. 2008;45:1319-28.

23. Huis In 't Veld EM, Makine C, Nouwen A, Karşıdağ C, Kadıoğlu P, Karşıdağ K, Pouwer F. Validation of the Turkish version of the problem areas in diabetes scale. Cardiovasc Psychiatry Neurol. 2011;2011:315068. https:// doi.org/10.1155/2011/315068

24. Miller ST, Elasy TA. Psychometric evaluation of the problem areas in diabetes (PAID) survey in Southern, rural African American women with Type 2 diabetes. BMC Public Health. 2008;8:70. https://doi.org/10.1186/ 1471-2458-8-70.

25. Beaton DE, Bombardier C, Guillemin F, Ferraz MB. Guidelines for the process of cross-cultural adaptation of self-report measures. Spine (Phila Pa 1976). 2000;25:3186-91.

26. Lygidakis C, Uwizihiwe JP, Kallestrup P, Bia M, Condo J, Vögele C. Community-and mHealth-based integrated management of diabetes in primary healthcare in Rwanda ( $D^{2}$ Rwanda): the protocol of a mixed-methods study including a cluster randomised controlled trial. BMJ Open. 2019;9:e028427.

27. Kline RB. Principles and practice of structural equation modeling. 3rd ed. New York: Guilford Press; 2011

28. Wang J, Wang X. Structural equation modeling: applications using Mplus. New York: Wiley; 2012.

29. Park P, Simmons RK, Prevost AT, Griffin SJ. Screening for type 2 diabetes is feasible, acceptable, but associated with increased short-term anxiety: a randomised controlled trial in British general practice. BMC Public Health. 2008:8:350. https://doi.org/10.1186/1471-2458-8-350.

30. Li C-H. Confirmatory factor analysis with ordinal data: comparing robust maximum likelihood and diagonally weighted least squares. Behav Res Methods. 2015;48:936-49.

31. Wang J, Wang X. Structural equation modeling: applications using Mplus. 2nd ed. New York: Wiley; 2019.

32. Byrne BM. Structural equation modeling with Mplus: Basic concepts, applications, and programming. New York: Taylor \& Francis; 2011.

33. Hu L, Bentler PM. Cutoff criteria for fit indexes in covariance structure analysis: conventional criteria versus new alternatives. Struct Equ Model A Multidiscip J. 1999;6:1-55. https://doi.org/10.1080/10705519909540118.
34. Yu C-Y. Evaluating cutoff criteria of model fit indices for latent variable models with binary and continuous outcomes, Los Angeles; 2002.

35. Lloret S, Ferreres A, Hernández A, Tomás I. The exploratory factor analysis of items: guided analysis based on empirical data and software. An Psicol. 2017;33:417-32.

36. Fritz CO, Morris PE, Richler JJ. Effect size estimates: current use, calculations, and interpretation. J Exp Psychol Gen. 2012;141:2-18.

37. Akoglu H. User's guide to correlation coefficients. Turk J Emerg Med. 2018;18:91-3.

38. Schober P, Boer C, Schwarte LA. Correlation coefficients: appropriate use and interpretation. Anesth Analg. 2018;126:1763-8.

39. Huang M-F, Courtney M, Edwards H, McDowell J. Validation of the Chinese version of the problem areas in diabetes (PAID-C) scale. Diabetes Care. 2010;33:38-40.

40. Melkus GD, Spollett G, Jefferson V, Chyun D, Tuohy B, Robinson T, et al. A Culturally competent intervention of education and care for black women with type 2 diabetes. Appl Nurs Res. 2004;17:10-20.

41. Özcan B, Rutters F, Snoek FJ, Roosendaal M, Sijbrands EJ, Elders PJM, et al. High diabetes distress among ethnic minorities is not explained by metabolic, cardiovascular, or lifestyle factors: findings from the dutch diabetes pearl cohort. Diabetes Care. 2018;41:1854LP - 1861.

42. Schmidt CB, Potter van Loon BJ, Torensma B, Snoek FJ, Honig A. Ethnic minorities with diabetes differ in depressive and anxiety symptoms and diabetes-Distress. lafusco D, editor. J Diabetes Res. 2017;2017:1204237. https://doi.org/10.1155/2017/1204237.

43. Welch GW, Jacobson AM, Polonsky WH. The problem areas in diabetes scale. An evaluation of its clinical utility. Diabetes Care. 1997;20:760-6.

44. Gois C, Akiskal H, Akiskal K, Figueira ML. Depressive temperament, distress, psychological adjustment and depressive symptoms in type 2 diabetes. J Affect Disord. 2012;143:1-4.

45. Akena D, Kadama P, Ashaba S, Akello C, Kwesiga B, Rejani L, et al. The association between depression, quality of life, and the health care expenditure of patients with diabetes mellitus in Uganda. J Affect Disord. 2015;174:7-12.

46. Mukeshimana M, Chironda G. Depression and associated factors among the patients with type 2 diabetes in Rwanda. Ethiop J Health Sci. 2019;29:709-18.

47. Munyandamutsa N, Mahoro Nkubamugisha P, Gex-Fabry M, Eytan A. Mental and physical health in Rwanda 14 years after the genocide. Soc Psychiatry Psychiatr Epidemiol. 2012;47:1753-61. https://doi.org/10.1007/ s00127-012-0494-9.

48. Schmitt A, Reimer A, Kulzer B, HaakT, Ehrmann D, Hermanns N. How to assess diabetes distress: comparison of the Problem areas in diabetes scale (PAID) and the diabetes distress scale (DDS). Diabet Med. 2016;33:835-43.

49. Gross CC, Scain SF, Scheffel R, Gross JL, Hutz CS. Brazilian version of the problem areas in diabetes scale (B-PAID): validation and identification of individuals at high risk for emotional distress. Diabetes Res Clin Pract. 2007;76:455-9. https://doi.org/10.1016/j.diabres.2006.09.022.

50. Tapela N, Habineza H, Anoke S, Harerimana E, Mutabazi F, Hedt-Gauthier $B$, et al. Diabetes in rural Rwanda: high retention and positive outcomes after 24 months of follow-up in the setting of chronic care integration. Int J Diabetes Clin Res 3:058. https://doi.org/10.23937/2377-3634/1410058.

51. Gill GV, Mbanya J-C, Ramaiya KL, Tesfaye S. A sub-Saharan African perspective of diabetes. Diabetologia. 2008;52:8. https://doi.org/10.1007/ s00125-008-1167-9.

52. Mauvais-Jarvis F, Sobngwi E, Porcher R, Riveline J-P, Kevorkian J-P, Vaisse C, et al. Ketosis-Prone type 2 diabetes in patients of Sub-Saharan African origin. Diabetes. 2004;53:645LP - 653.

53. Bavuma C, Sahabandu D, Musafiri S, Danquah I, McQuillan R, Wild S. Atypical forms of diabetes mellitus in Africans and other non-European ethnic populations in low- and middle-income countries: a systematic literature review. J Glob Health. 2019;9(2):020401. https://doi.org/10. 7189/jogh.09.020401.

\section{Publisher's Note}

Springer Nature remains neutral with regard to jurisdictional claims in published maps and institutional affiliations. 